\title{
A tribute to George E. Palade
}

eorge E. Palade (1912-2008) received his MD from the School of Medicine of the University of Bucharest, Romania. He was a member of the faculty of that school until 1945, when he came to the United States for postdoctoral studies. Palade joined Albert Claude at the Rockefeller Institute for Medical Research in 1946 and was appointed assistant professor there in 1948. He progressed to full professor and was head of the Laboratory of Cell Biology until 1973, when he moved to Yale University as professor to establish the Section of Cell Biology. He wrote that his move to Yale was driven by "... my belief that the time had come for fruitful interactions between the new discipline of Cell Biology and the traditional fields of interest of medical schools, namely Pathology and Clinical Medicine" (1). Palade was chair of the Section of Cell Biology from 1975 to 1983, when, upon his retirement as chair, it became the Department of Cell Biology. That same year he was named Senior Research Scientist, Professor Emeritus of Cell Biology, and Special Advisor to the Dean. In 1990, Palade moved to the University of California, San Diego. Once again, he welcomed a new challenge and began an entirely new career as Professor of Medicine in Residence and Dean for Scientific Affairs in the School of Medicine. He started the new Department of

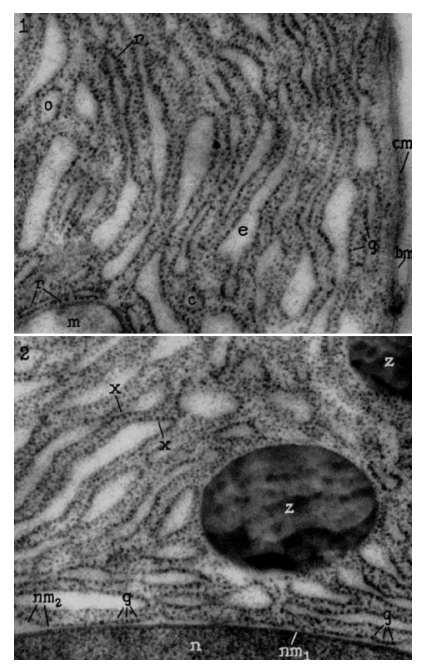

Figure 1

Palade first described the ER. Reproduced with permission from the Journal of Biophysical and Biochemical Cytology (7).
Cellular and Molecular Medicine and transformed the development of basic sciences at UCSD.

Palade's scientific contributions, which spanned nearly 50 years, led to a fundamental understanding of the structure and function of cells and defined the new field of cell biology. They opened novel areas of research that countless scientists in diverse fields now explore. Reminiscing about the early days at the Rockefeller when the field of cell biology was conceived, Palade wrote, "After so many years, it is difficult to recapture in words the atmosphere of intense activity, remarkable achievements, great excitement, and unlimited optimism that prevailed in the laboratory, which otherwise looked like an unattractive dungeon sunk in the third basement of one of the old buildings of The Rockefeller Institute." "The new field had virtually no tradition; everybody working in it came from some other province in natural sciences." "Added to all this excitement was a pervading free spirit - often irreverent but always helpful, because it acted as an antidote against imagined grandeur. Keith Porter was responsible for a good part of that spirit" $(2,3)$. Fortunately, that spirit still exists in our field.

Palade, along with Keith Porter and others at the Rockefeller, was a founder of the American Society for Cell Biology in 1960, with approximately 230 members at its first meeting in Chicago. The ASCB has grown to a membership of approximately 10,000, indicative of current activity in the field. Palade was its president in 1976 . He was active in establishing the Journal of Cell Biology (originally the Journal of Biochemical and Biophysical Cytology) in 1955, as well as the Annual Reviews of Cell Biology in 1985. Palade was influential as a member of the advisory panel to the director of the NIH in ensuring that support for the basic sciences was recognized. The importance of basic science in human pathophysiology was indicated in his acceptance speech for the Nobel Prize in 1974: "Cell biology finally makes possible a century-old dream: that of analysis of diseases at the cellular level, the first step toward their final control" (4). Physician-scientists in all fields will immediately recognize the importance of his

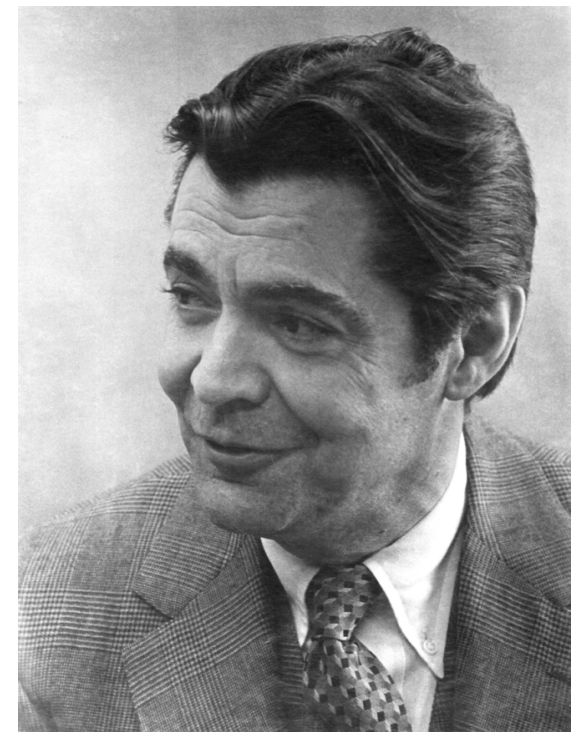

Figure 2

A cell biology giant. Photo courtesy of the author.

contributions to medicine, a reflection of his training as an MD, which enabled him to view his science in the larger context of human disease.

Palade was elected to membership in the National Academy of Sciences, the Institute of Medicine, and the American Academy of Arts and Sciences. In 1974, he received the Nobel Prize in Physiology or Medicine (shared with Albert Claude and Christian de Duve). He was also a recipient of the National Medal of Science (USA) in 1986, the Albert Lasker Award, the Gairdner Special Award, and many other honors. In announcing the 1974 prize, the Nobel Committee said of Palade, "He added important methodological improvements both to the differential centrifugation and to the electron microscopy. In particular, he became instrumental in combing the two techniques ... in order to obtain biologically basic information" (5).

He was best known for his pioneering work in elucidating the pathway for synthesis and vectorial transport of proteins along the secretory pathway (6). This is exemplified in this classic electron micrograph taken by Palade from his 1955 article "A small particulate component of the cytoplasm” (7) (Figure 1). There, he first described the association of what were 
subsequently determined to be ribosomes with membranes. He and Porter later named this structure the endoplasmic reticulum. Together, they and the group at the Rockefeller developed techniques for fixation and thin sectioning of cells, for fractionating cells by centrifugation, and for studying the fractions by electron microscopy and biochemistry - the essence of cell biology.

After a long illness, Palade passed away quietly at home on October 8, 2008, at the age of 95 . Palade will be remembered and honored at Yale, the Rockefeller, and UCSD, where he has had a profound influence much beyond the boundaries of his laboratory. He inspired so many students, postdocs, and faculty to ask important questions and to teach according to the wonderful example set by both him and his wife, cell biologist Marilyn Farquhar. As David Sabatini, one of his early graduate students at the Rockefeller, wrote of Palade (Figure 2) in 2004, "Palade's personal attributes make him one of the most admired and beloved figures in today's scientific scene. Palade not only has a powerful intellect that allows him quickly to cut to the essence of a scientific problem and propose for it a feasible solution, but is also a man of great human qualities - warm and sensitive, polite and gracious" (8). His loss is profound.

\section{James D. Jamieson}

Department of Cell Biology, Yale University School of Medicine, New Haven, Connecticut, USA. E-mail: james.jamieson@yale.edu.
1. Palade, G.E. 1974. Autobiography. http://nobelprize.org/nobel_prizes/medicine/laureates/1974/ palade-autobio.html.

2. Palade, G.E. 1977. Keith Roberts Porter and the development of contemporary cell biology. J. Cell Biol. 75:D3-D18.

3. Tartakoff, A.M. 2002. George Emil Palade: charismatic virtuoso of cell biology. Nat. Rev. Mol. Cell Biol. 23:871-876.

4. Palade, G.E. 1974. Banquet speech: George E. Palade's speech at the Nobel Banquet, December 10, 1974. http://nobelprize.org/nobel_prizes/medicine/laureates/1974/palade-speech.html.

5. The Nobel Assembly at Karolinska Institutet. 1974. The Nobel Prize in Physiology or Medicine 1974 [press release]. http://nobelprize.org/nobel_prizes/ medicine/laureates/1974/press.html.

6. Palade, G. 1975. Intracellular aspects of the process of protein synthesis. Science. 189:347-358.

7. Palade, G.E., et al. 1955. A small particulate component of the cytoplasm. J. Biophys. Biochem. Cytol. 1:59-68.

8. UCSD. 2004. Program for the dedication of the George Palade Laboratories for Cellular and Molecular Medicine. March 16. 